\title{
ETNOMATEMATIKA : EKSPLORASI PRASASTI PENINGGALAN KERAJAAN DI JAWA TIMUR
}

\author{
Dilla Dwi Cahyani ${ }^{1}$, Mega Teguh Budiarto ${ }^{2}$ \\ ${ }^{1,2}$ Universitas Negeri Surabaya, Jl. Ketintang, Surabaya, Indonesia \\ dillacahyani16030174066@mhs.unesa.ac.id
}

\begin{abstract}
Cultures, mathematics, and education can be combined and acquired through a study called ethnomathematics. The role of ethnomathematics is quite important in mathematics learning. This study aims to explore and describe the concept of mathematics in eight inscriptions from East Java and its functions in mathematics learning. The chosen ethnomathematics objects are Kubu-Kubu Inscription, Kaladi inscription, Harinjing Inscription, Jeru-Jeru Inscription, Linggasuntan Inscription, Gulung-Gulung Inscription, Baru Inscription, and Kamalagyan Inscription. The type of this study is a qualitative study with an ethnographic approach. Data obtained by literature studies, interviews, and documentation. The mathematical concepts of the eight inscriptions are found in the physical form, the ornament, and the text contained in the inscriptions. The mathematical concepts there are plane shapes such as triangle, rectangle, trapezoid, circle, and pentagon; transformation geometry such as translation and reflection; statistical concept; sets concept; units of measure; and use of number symbols. Those mathematical concepts can be used by the teacher as a material of mathematics learning in $3^{\text {rd }}, 4^{\text {th }}, 6^{\text {th }}$ grade of elementary school and $7^{\text {th }}, 8^{\text {th }}, 9^{\text {th }}$ grade of junior high school. So that students can also learn history, culture, and increase their character values though cultural heritage.
\end{abstract}

Keywords: Ethnomathematics, Mathematical Conception, Inscriptions in East Java

\begin{abstract}
Abstrak
Budaya, matematika, maupun pendidikan dapat dipadukan dan diperoleh melalui suatu kajian yang disebut etnomatematika. Peran etnomatematika cukup penting dalam pembelajaran matematik. Penelitian dilakukan untuk menggali dan mendeskripsikan konsep matematika pada delapan prasasti yang berasal dari Jawa Timur tersebut dan penggunaannya dalam pembelajaran matematika. Objek etnomatematika yang dipilih diantaranya Prasasti Kubu-Kubu, Prasasti Kaladi, Prasasti Harinjing, Prasasti Jeru-Jeru, Prasasti Linggasuntan, Prasasti Gulung-Gulung, Prasasti Baru, dan Prasasti Kamalagyan. Jenis penelitian ini adalah penelitian kualitatif dengan pendekatan etnografi. Data diperoleh dengan cara studi literatur, wawancara dan dokumentasi. Konsep matematika pada kedelapan prasasti tersebut terdapat pada bentuk fisik prasasti, hiasan prasasti, dan tulisan yang termuat dalam prasasti. Konsep matematika tersebut diantaranya: konsep bangun datar yaitu segitiga, persegipanjang, trapesium, lingkaran, dan segi lima; konsep geometri transformasi yaitu translasi dan refleksi; konsep statistika; konsep himpunan; konsep satuan ukuran; dan penggunaan lambang bilangan. Konsep matematika ini dapat dimanfaatkan guru sebagai bahan ajar matematika untuk jenjang SD kelas III, IV, dan VI, serta SMP kelas VII, VIII, dan IX. Sedemikian hingga siswa juga dapat belajar sejarah, budaya, dan menambah nilai karakter melalui peninggalan budaya.
\end{abstract}

Kata Kunci : Etnomatematika, Konsep Matematika, Prasasti di Jawa Timur

\section{PENDAHULUAN}

Matematika dan budaya merupakan dua hal yang tidak dapat dihindari dalam kehidupan seharihari serta saling berkaitan satu sama lain. Matematika dan budaya tumbuh secara bersama dalam lingkungan masyarakat sehingga pengetahuan matematika seseorang dipengaruhi oleh latar budayanya. Indonesia mempunyai beragam budaya maka dalam penerapannya matematika di setiap budaya juga beragam. Sebagai contoh masyarakat Melayu Riau memiliki sistem bilangan khusus dalam membangun rumah tempat tinggal yang mencerminkan beberapa filosofi bangun rumah(Nuh \& Dardiri, 2017). Selanjutnya, Rumah adat Madura yang ada di pemukiman Taneyan Lanjang berciri khas rumah berderet dari Barat ke Timur dengan halaman panjang berbentuk persegipanjang, serta mempunyai ukiran-ukiran khas Madura (Budiarto, 2016b). Kemudian, rumah adat Toraja disebut 
Tongkonan, mempunyai ukiran unik dan indah yang secara tidak sengaja telah menunjukkan penggunakan ide dan konsep matematika seperti konsep geometri dalam budaya dan kehidupan masyarakat Toraja (Budiarto, 2016b). Ketiga contoh tersebut cukup menjelaskan bahwa pengetahuan matematika seseorang tumbuh bersama budaya dalam lingkungan masyarakat.

Matematika merupakan bentuk budaya yang terintegrasi pada seluruh kehidupan masyarakat (A. Bishop, 1994). Hal tersebut dapat diartikan bahwa dalam budaya dapat ditemukan konsep matematika yang berbagai macam sehingga dapat memperjelas bahwa matematika dan budaya saling berkaitan. Jembatan antara budaya dan matematika adalah langkah penting untuk mengetahui cara berpikir dapat membentuk berbagai bentuk matematika sehinga mempermudah siswa dalam memahami matematika (A. J. Bishop, 1997; Rosa \& Clark, 2011; Wahyuni, Aji, Tias, \& Sani, 2013; Zaenuri \& Dwidayati, 2018). Matematika dalam budaya dapat dimanfaatkan sebagai sumber belajar matematika yang konkret. Budaya, matematika, maupun pendidikan dapat dipadukan dan diperoleh melalui suatu kajian dalam meneliti cara-cara khusus kelompok budaya tertentu untuk memahami, menerapkan konsep dan praktik matematika yang disebut dengan istilah etnomatematika. Etnomatematika pertama kali diperkenalkan oleh D'Ambrosio, seorang matematikawan Brazil pada tahun 1977. Etnomatematika dapat didefinisikan sebagai suatu cara yang dilakukan masyarakat dari budaya tertentu dalam menggunakan ide dan konsep matematika (Budiarto, 2016a; D’Ambrosio, 1985, 1999; Risdiyanti \& Prahmana, 2018; Rosa \& Clark, 2011). Objek etnomatematika merupakan objek budaya yang mempunyai konsep matematika pada suatu masyarakat. Objek etnomatematika dapat berupa permainan tradisional, kerajinan tradisional, artefak, dan aktivitas (kegiatan) yang berwujud kebudayaan (Hardiarti, 2017).

Salah satu objek yang menjadi cagar budaya di Jawa Timur yang dapat ditemukan konsep matematika yaitu prasasti. Jika dipandang dalam perpektif matematika terdapat beberapa ide dan konsep pada prasasti di Indonesia. Contohnya prasasti Tugu peninggalan Kerajaan Tarumanegara, prasasti ini memuat ide dan konsep matematika seperti pelafalan bilangan ordinal dan kardinal, interval waktu dan panjangnya, siklus/daur dan modulo, satuan panjang dan waktu, konsep himpunan, dan penggunaan bilangan basis sepuluh (Prabowo, Tripena, \& Sugandha, 2017). Banyak prasasti peninggalan kerajaan yang tersebar di daerah Jawa Timur. Beberapa prasasti diantaranya, yaitu Prasasti Kubu-Kubu, Prasasti Kaladi, Prasasti Harinjing, Prasasti Linggasuntan, Prasasti GulungGulung, Prasasti Jeru-Jeru, Prasasti Baru, dan Prasasti Kamalagyan. Prasasti Kubu-Kubu, Prasasti Kaladi, Prasasti Harinjing, Prasasti Linggasuntan, Prasasti Gulung-Gulung, dan Prasasti Jeru-Jeru dikeluarkan oleh Kerajaan Mataram Kuna pada sekitar abad 8-9 M. Prasasti Kubu-Kubu, Prasasti Prasasti Linggasuntan, Prasasti Gulung-Gulung, dan Jeru-Jeru ditemukan di Malang. Sedangkan Prasasti Kaladi ditemukan di Mojokerto, dan Prasasti Harinjing ditemukan di Kediri. Selanjutnya, Prasasti Baru dan Prasasti Kamalagyan dikeluarkan oleh Kerajaan Kahuripan pada sekitar abad 10 M yang masing-masing ditemukan di Surabaya dan Mojokerto. Kehidupan masyarakat pada masa kerajaan yang tercantum dalam prasasti diantaranya tentang sistem penganggalan, penentuan batas 
sima / tanah perdikan, hukum, pajak, kemenangan raja, pendirian bangunan suci, silsilah kerajaan, gambaran tentang kehidupan politik, perbanditan, dsb (Ardiyanto, 2015). Prasasti Kubu-Kubu, Prasasti Kaladi, Prasasti Harinjing, Prasasti Linggasuntan, Prasasti Gulung-Gulung, Prasasti Jeru-Jeru, Prasasti Baru, dan Prasasti Kamalagyan dikeluarkan sebagai anugerah raja karena beberapa alasan tertentu serta memuat sistem penganggalan, penentuan batas sima / tanah perdikan, dan pajak.

Ide dan konsep matematika pada kedelapan prasasti di atas dapat ditemukan mulai dari bentuk dan ukuran hingga tulisan pada setiap prasasti. Kedelapan prasasti tersebut sudah dialihaksarakan dan diterjemahkan oleh beberapa peneliti lain sehingga dapat diidentifikasi penggunaan ide dan konsep matematika dalam tulisan yang dimuat. Selain itu, bentuk fisik dari prasasti-prasasti tersebut masih utuh dan terawat dengan baik. Dengan demikian, prasasti-prasasti tersebut dapat dijadikan sebagai objek etnomatematika guna untuk menggali dan mendeskripsikan konsep matematika pada kedelapan prasasti yang berasal dari Jawa Timur tersebut dan penggunaannya dalam pembelajaran matematika.

\section{METODE}

Jenis penelitian ini adalah penelitian kualitatif dengan menggunakan pendekatan etnografi. Data yang diambil berupa data mengenai konsep matematika yang ada pada delapan prasasti peninggalan kerajaan di Jawa Timur, yaitu Prasasti Kubu-Kubu, Prasasti Kaladi, Prasasti Harinjing, Prasasti Linggasuntan, Prasasti Gulung-Gulung, Prasasti Jeru-Jeru, Prasasti Baru, dan Prasasti Kamalagyan yang diperoleh dari pengambilan data berupa kajian dari berbagai literatur. Data lainnya berupa wawancara dan dokumentasi dengan kurator museum nasional dan pengkaji budaya BPCB Jatim yang digunakan untuk mengonfirmasi dan melengkapi data. Keabsahan data menggunakan triangulasi teknik (metode), yaitu mengecek kevalidan data dengan menggunakan lebih dari satu teknik pengumpulan data guna mendapatkan data yang sama (Zamzam \& Firdaus, 2018). Analisis data menggunakan pendekatan etnografi yang dikemukakan oleh Spradley (2006) yaitu analisis domain dan analisis taksonomi.

\section{HASIL}

Berdasarkan data yang diperoleh, konsep matematika pada Prasasti Kubu-Kubu, Prasasti Kaladi, Prasasti Harinjing, Prasasti Linggasuntan, Prasasti Gulung-Gulung, Prasasti Jeru-Jeru, Prasasti Baru, dan Prasasti Kamalagyan berdasarkan bentuk fisik prasasti, hiasan pada prasasti, dan isi tulisan pada prasasti serta penggunaannya dalam pembelajaran matematika adalah sebagai berikut.

\section{Bentuk Fisik Prasasti}

Berdasarkan bentuk fisiknya Prasasti Kubu-Kubu, Prasasti Kaladi, Prasasti Harinjing, Prasasti JeruJeru, Prasasti Linggasuntan, Prasasti Gulung-Gulung, Prasasti Baru, dan Prasasti Kamalagyan dapat di kategorikan menjadi 4 kelompok, yaitu (1) Prasasti berbentuk lempengan tembaga; (2) Prasasti batu berbentuk stele dengan puncak setengah lingkaran; (3) Prasasti batu berbentuk stele dengan puncak kurawal (akolade); (4) Prasasti batu berbentuk stele dengan puncak lancip. 
Pertama, prasasti berbentuk lempengan tembaga yaitu Prasasti Kubu-Kubu dan Prasasti Kaladi Prasasti Kubu-Kubu dikeluarkan pada tahun 827 Saka (905M) dan Prasasti Kaladi pada tahun 831 Śaka (909 M) oleh Raja Balitung dari Kerajaan Mataram Kuna. Prasasti Kubu-Kubu terbuat dari 7 buah lempengan yang berukuran $35,3 \mathrm{~cm} \times 5,4 \mathrm{~cm}$ dan lempengan yang ke-2 dari prasasti ini dinyatakan hilang. Sedangkan Prasasti Kaladi terbuat dari 10 buah lempengan yang berukuran $43 \mathrm{~cm} \times 11 \mathrm{~cm}$ dan dua diantara sepuluh lempengan prasasti hilang, yaitu lempengan ke- 3 dan ke-5. Berdasarkan hasil wawancara prasasti yang berbentuk lempengan tembaga dapat disimpan secara pribadi, berbeda dengan prasasti batu yang ditujukan untuk umum atau dapat dilihat oleh umum.

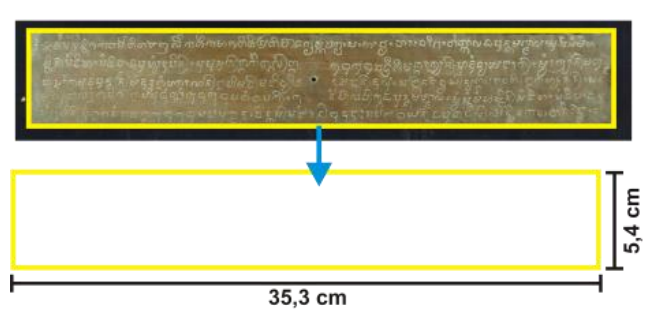

Gambar 1. Ukuran lempengan Prasasti Kubu-

Kubu

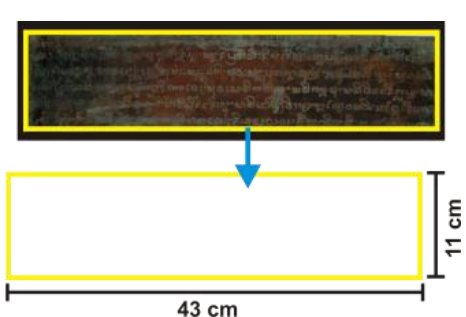

Gambar 2. Ukuran lempengan Prasasti

Kaladi

Pada bentuk fisik Prasasti Kubu-Kubu dan Prasasti Kaladi dapat ditemukan konsep matematika yaitu persegipanjang. Hal ini dapat diketahui dari definisi persegipanjang yaitu suatu segiempat dengan dua pasang sisi sejajar dan salah satu sudutnya siku-siku (Suharjana, Markaban, \& Sasongko, 2013). Jika dipandang dari depan, permukaan lempengan kedua prasasti tersebut menyerupai bangun persegipanjang seperti pada gambar 1 dan gambar 2. Gambar 1 dan gambar 2 menunjukkan ukuran pada lempengan Prasasti Kubu-Kubu dan Prasasti Kaladi yang digambarkan melalui konsep matematika bangun datar persegipanjang

Kedua, prasasti batu yang berbentuk stele dengan puncak setengah lingkaran yaitu Prasasti Harinjing dan Prasasti Linggasuntan. Prasasti Harinjing terdiri atas tiga piagam yang ditulis dalam satu batu prasasti yang masing-masing menyebutkan penanggalan tahun 726 Saka (804 M), 843 Saka (921 M), dan 849 Saka (927 M). Prasasti Harinjing mempunyai ukuran $75 \mathrm{~cm} \times 46 \mathrm{~cm} \times 120 \mathrm{~cm}$. Sedangkan Prasasti Linggasuntan dikeluarkan pada tahun 851 Saka (929 M) oleh Raja Sindok dari Kerajaan Mataram Kuna. Prasasti Linggasuntan mempunyai ukuran $(99-109) \mathrm{cm} \times 31 \mathrm{~cm} \times$ $174 \mathrm{~cm}$. Pada sisi depan bagian bawah prasasti diberi bentuk seperti tangga yang terdiri dari dua undakan. Undakan pertama berukuran $99 \mathrm{~cm} \times 12 \mathrm{~cm} \times 12 \mathrm{~cm}$ dan di tengah undakan itu ada pahatan bunga (teratai) setengah mekar. Undakan kedua berukuran $99 \mathrm{~cm} \times 8,5 \mathrm{~cm} \times 14 \mathrm{~cm}$. 


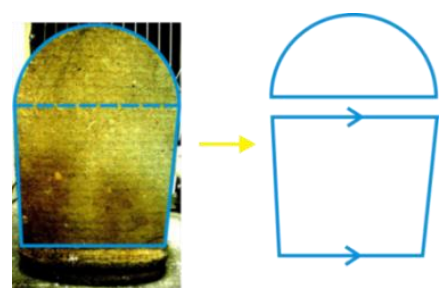

Gambar 3. Pola bentuk setengah lingkaran dan trapesium pada batu Prasasti Harinjing

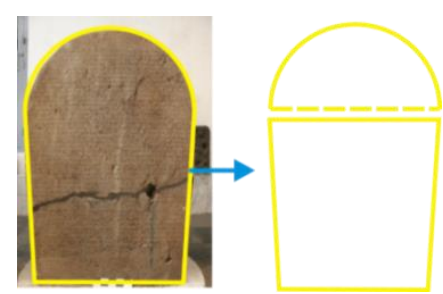

Gambar 4. Pola bentuk setengah lingkaran dan trapesium pada batu Prasasti

Linggasuntan

Pada bentuk fisik Prasasti Harinjing dan Prasasti Linggasuntan dapat ditemukan konsep matematika bangun datar lingkaran dan trapesium. Hal ini dapat diketahui dari definisi lingkaran yaitu himpunan titik-titik pada bidang datar yang berjarak sama ke sebuah titik (titik pusat), sedangkan trapesium yaitu segiempat yang memiliki tepat satu pasang sisi yang sejajar (Suharjana et al., 2013; Susanah, 2017). Jika dipandang dari depan ataupun belakang, permukaan Prasasti Harinjing dan Prasasti Linggasuntan tampak menyerupai gabungan bangun datar lingkaran dan trapesium. Titik pusat lingkaran pada bentuk prasasti ini terletak pada perpotongan garis vertikal yang melalui titik tengah puncak prasasti dengan garis horizontal yang menghubungkan bangun lingkaran dan trapesium. Gambar 3 dan gambar 4 menunjukkan pola bentuk setengah lingkaran dan trapesium pada batu Prasasti Harinjing dan Prasasti Linggasuntan yang digambarkan melalui konsep matematika bangun datar lingkaran dan trapesium.

Ketiga, prasasti batu berbentuk stele dengan puncak kurawal (akolade) yaitu Prasasti GulungGulung dan Prasasti Jeru-Jeru. Prasasti Gulung-Gulung dikeluarkan pada tahun 851 Saka (929 M) dan Prasasti Jeru-Jeru dikeluarkan pada tahun 852 Saka (930M) oleh Raja Sindok dari Kerajaan Mataram Kuna. Prasasti Gulung-Gulung mempunyai ukuran $76 \mathrm{~cm} \times 21,5 \mathrm{~cm} \times(122-150) \mathrm{cm}$. Sedangkan Prasasti Jeru-Jeru mempunyai ukuran $96 \mathrm{~cm} \times 20 \mathrm{~cm} \times 120 \mathrm{~cm}$.

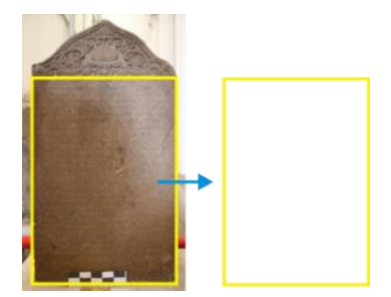

Gambar 5. Pola persegipanjang pada

Prasasti Jeru-Jeru

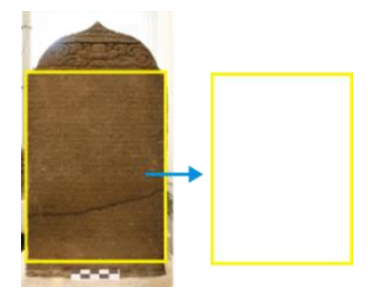

Gambar 6. Pola persegipanjang pada

Prasasti Gulung-Gulung

Konsep matematika yang terkandung dalam Prasasti Jeru-Jeru dan Prasasti Gulung-Gulung dapat ditemukan pada bentuk fisiknya. Pada bentuk fisik kedua prasasti tersebut dapat ditemukan konsep matematika bangun datar persegipanjang. Hal ini dapat diketahui dari definisi Persegipanjang merupakan segiempat yang dua pasang sisinya sejajar dan salah satu sudutnya siku-siku (Suharjana et al., 2013). Jika dipandang baik dari depan ataupun belakang bagian permukaan batu Prasasti Jeru-Jeru dan Gulung-Gulung yang memuat pahatan aksara memiliki bentuk bangun segiempat yang 
menyerupai persegipanjang. Gambar 5 dan gambar 6 menunjukkan pola bentuk persegipanjang pada permukaan batu Prasasti Jeru-Jeru dan Prasasti Gulung-Gulung yang digambarkan melalui konsep matematika bangun datar persegipanjang.

Keempat, prasasti batu berbentuk stele dengan puncak lancip yaitu Prasasti Baru dan Prasasti Kamalagyan. Prasasti Baru dikeluarkan pada tahun 952 Saka (1030 M) dan Prasasti Kamalagyan pada tahun 959 Saka (1037 M) oleh Raja Airlangga dari Kerajaan Kahuripan. Prasasti Baru mempunyai ukuran $96 \mathrm{~cm} \times 33 \mathrm{~cm} \times 174 \mathrm{~cm}$, sedangkan Prasasti Kamalagyan mempunyai ukuran $116 \mathrm{~cm} \times$ $29 \mathrm{~cm} \times 219 \mathrm{~cm}$.

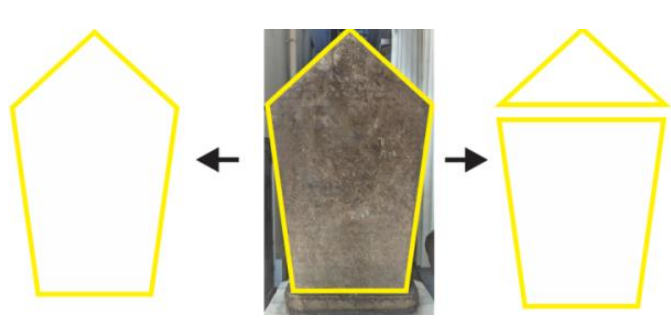

Gambar 7. Pola bangun segilima, segitiga dan trapesium pada Prasasti Baru

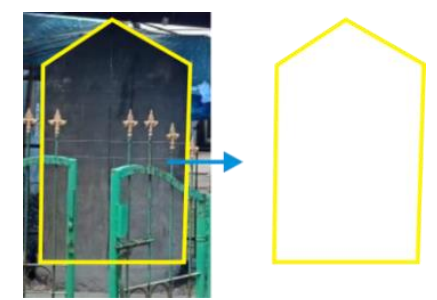

Gambar 8. Pola bangun segilima pada Prasasti Kamalagyan

Konsep matematika yang terkandung dalam Prasasti Baru dan Prasasti Kamalagyan dapat ditemukan pada bentuk fisiknya. Pada bentuk fisik kedua prasasti tersebut dapat ditemukan konsep matematika bangun datar segilima. Hal ini dapat di ketahui dari definisi segilima yaitu segilima adalah segibanyak yang mempunyai lima sisi (Karim \& Hidayanto, 2014). Bangun datar segilima pada kedua prasasti merupakan gabungan dari bangun datar segitiga dan trapesium. Segitiga adalah bangun datar yang terjadi dari tiga ruas garis yang setiap dua ruas garis bertemu ujungnya, sedangkan trapesium adalah segiempat yang memiliki tepat satu pasang sisi sejajar (Suharjana et al., 2013). Jika dipandang baik dari depan ataupun belakang bagian permukaan batu Prasasti Baru dan Prasasti Kamalagyan memiliki bentuk bangun datar segilima yang merupakan gabungan bangun datar segitiga dan trapesium. Gambar 7 dan gambar 8 menunjukkan pola bangun segilima pada Prasasti Baru dan Prasasti Kamalagyan yang digambarkan melalui konsep matematika bangun datar segilima.

Pada pembelajaran matematika di sekolah, baik Prasasti Kubu-Kubu, Prasasti Kaladi, Prasasti Gulung-Gulung, Prasasti Jeru-Jeru, Prasasti Baru, maupun Prasasti Kamalagyan dapat dijadikan objek pada pembelajaran bangun datar untuk kelas III sesuai KD 3.6 yaitu menjelaskan dan menentukan keliling bangun datar serta Kelas IV sesuai KD 3.9 yaitu menjelaskan dan menentukan keliling dan luas persegi, persegipanjang, dan segitiga serta hubungan pangkat dua dengan akar pangkat dua (Kemendikbud, 2018). Sedangkan Prasasti Harinjing dan Linggasuntan dapat dijadikan objek pada pembelajaran bangun datar untuk kelas VI sesuai KD 3.5 yaitu menjelaskan taksiran keliling dan luas lingkaran (Kemendikbud, 2018). Pada saat kelas VI siswa telah mendapatkan pembelajaran terkait keliling dan luas bangun datar segiempat dan segitiga sehingga bentuk dasar kedua prasasti tersebut 
dapat digunakan sebagai salah satu model matematika gabungan bangun datar lingkaran dan trapesium.

Prasasti Kubu-Kubu, Prasasti Kaladi, Prasasti Harinjing, Prasasti Linggasuntan, Prasasti Gulung-Gulung, Prasasti Jeru-Jeru, Prasasti Baru, dan Prasasti Kamalagyan merupakan objek yang kontekstual sehingga mempermudah peserta didik dalam mengenali bentuk dari bangun datar. Prasasti Kubu-Kubu, Prasasti Kaladi, Prasasti Gulung-Gulung, dan Prasasti Jeru-Jeru mempermudah peserta didik dalam mengenali bentuk dari bangun datar persegipanjang dan menjadi contoh benda yang memiliki bentuk persegipanjang serta dapat dijadikan sebagai objek dalam membuat soal matematika kontekstual berkaitan dengan keliling dan luas bangun datar persegipanjang. Kemudian, Prasasti Harinjing dan Prasasti Linggasuntan mempermudah peserta didik dalam mengenali bentuk dari gabungan bangun datar lingkaran dan trapesium serta objek dalam membuat soal matematika kontekstual berkaitan dengan keliling dan luas bangun datar gabungan. Sedangkan Prasasti Baru dan Prasasti Kamalagyan mempermudah peserta didik dalam mengenali bentuk dari bangun datar segilima dan menjadi contoh benda yang memiliki bentuk segilima serta dapat dijadikan sebagai objek dalam membuat soal matematika kontekstual berkaitan dengan keliling dan luas bangun datar segilima atau gabungan bangun datar segiempat dan segitiga.

\section{Hiasan Pada Prasasti}

Sebagian prasasti mempunyai hiasan-hiasan unik berupa ukiran khusus yang menjadi ciri khasnya masing-masing, namun sebagian prasasti juga ada yang tidak mempunyai hiasan hanya terpahat tulisan aksara saja. Begitupun dengan Prasasti Kubu-Kubu, Prasasti Kaladi, Prasasti Harinjing, Prasasti Jeru-Jeru, Prasasti Linggasuntan, Prasasti Gulung-Gulung, Prasasti Baru, dan Prasasti Kamalagyan. Dari delapan prasasti tersebut empat prasasti diantaranya mempunyai hiasan, sedangkan empat lainnya tidak ditemukan hiasan pada prasasti. Empat prasasti tersebut yaitu Prasasti Harinjing, Prasasti Jeru-Jeru, Prasasti Gulung-Gulung, dan Prasasti Baru.

Prasasti Harinjing dan Prasasti Baru pada bagian alasnya terdapat hiasan berbentuk bunga padma (teratai) dengan kelopaknya yang menghadap ke atas dan ke bawah. Berdasarkan hasil wawancara, dalam kesenian Hindu-Buddha, teratai atau padma merupakan tanaman penting yang dianggap sebagai penanda dari penciptaan, kesucian, kelahiran yang suci, dan sebagainya. Hiasan bunga teratai atau padma di alas prasasti dapat digunakan sebagai bahan ajar matematika konsep translasi dan refleksi dalam materi geometri transformasi. Translasi (geseran) adalah jenis transformasi yang memetakan titik-titik pada suatu bidang dengan ruas garis berarah (vektor) tertentu, sedangkan refleksi adalah cerminan dari suatu objek dengan jarak dan ukuran yang sama (Budiarto, 2006, 2015). Pada gambar 11 dan gambar 13, S menunjukkan suatu pemetaan, sedangkan $\underline{\mathrm{AB}}$ dan $\underline{\mathrm{CD}}$ menunjukkan garis berarah (vektor). 


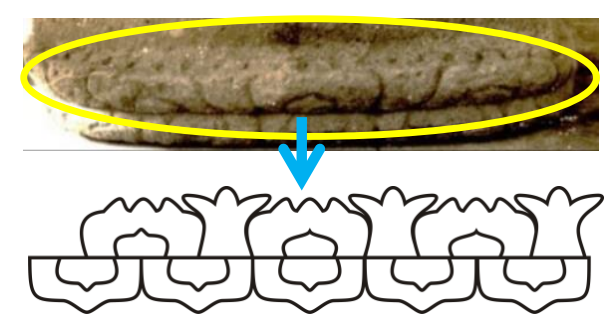

Gambar 9. Sketsa hiasan padma pada alas Prasasti Harinjing

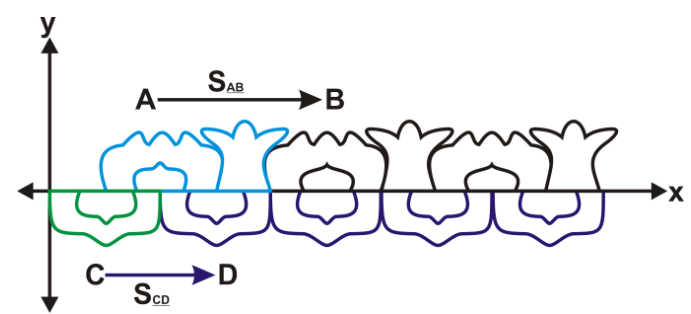

Gambar 10. Sketsa hasil transformasi translasi objek terhadap $S_{\underline{A B}}$ dan $S_{\underline{C D}}$

Gambar 11 menunjukkan proses translasi sepanjang garis horizontal membentuk objek baru sehingga seperti pengulangan objek sebelumnya dengan arah dan bentuk yang sama. Setiap titik pada objek yang berwarna biru dipetakan dengan $\mathrm{S}_{\underline{A B}}$ sehingga menghasilkan bayangan seperti objek yang berwarna hitam pada gambar 11. Selanjutnya, setiap titik pada objek yang berwarna hijau dipetakan dengan $\mathrm{S}_{\underline{\mathrm{D}}}$ sehingga menghasilkan bayangan seperti objek yang berwarna nila pada gambar 11 .

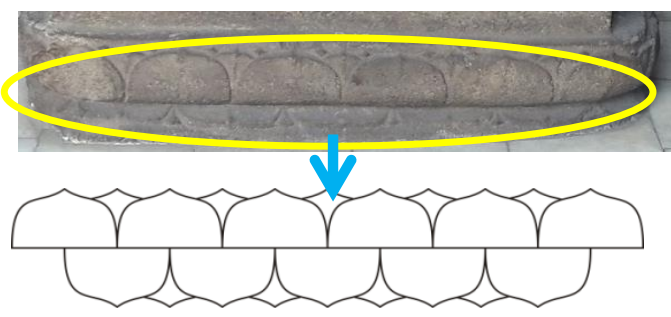

Gambar 11. Sketsa hiasan pada kaki

Prasasti Baru

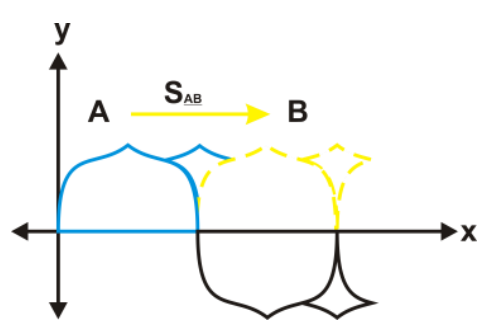

Gambar 12. Sketsa transformasi

translasi dan refleksi hiasan pada kaki

Prasasti Baru

Gambar 13 menunjukkan sketsa transformasi geometri translasi dan refleksi yang terdapat pada hiasan Prasasti Baru yang digambarkan melalui konsep matematika transformasi geometri translasi dan refleksi. Setiap titik pada objek yang berwarna biru dipetakan dengan $\mathrm{S}_{\underline{\mathrm{AB}}}$ menghasilkan bayangan seperti objek yang berwarna kuning, kemudian dilanjutkan dengan merefleksikan objek berwarna kuning terhadap sumbu- $x$ sehingga menghasilkan objek berwarna hitam. Refleksi adalah cerminan dari suatu objek dengan jarak dan ukuran yang sama (Budiarto, 2006). Pada pembelajaran matematika di sekolah, hiasan pada batu Prasasti Harinjing dan Prasasti Baru dapat dijadikan objek pada pembelajaran transformasi geometri untuk kelas IX sesuai KD 3.5 yaitu menjelaskan transformasi geometri (relfleksi, translasi, rotasi dan dilatasi) yang dihubungkan dengan masalah kontekstual (Kemendikbud, 2018).

Selain itu, pada batu Prasasti Baru terdapat hiasan berupa gambar burung garuda di dalam bingkai lingkaran. Hiasan tersebut dinamakan lancana Garudamukha di dalam bingkai lingkaran. Garuda digambarkan berbadan manusia berkepala burung dengan kepalanya menoleh ke kanan. Dari hasil wawancara didapat bahwa lancana Garudamukha merupakan lambang kerajaan Raja Airlangga. Selain itu, garuda merupakan simbol dari kebebasan. Hiasan tanda Garudamukha ini tepat berada di tengah bagian atas sisi depan prasasti seperti pada gambar 14 . 

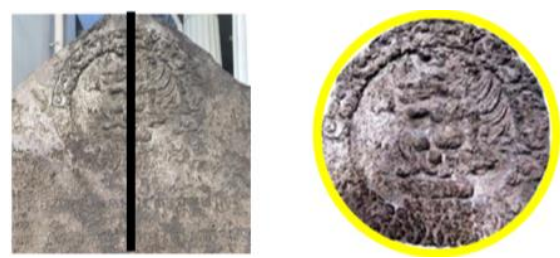

Gambar 13. Lancana Garudamukha pada Prasasti Baru

Gambar 14 menunjukkan pola bentuk bangun datar lingkaran yang terdapat pada hiasan Lancana Garudamukha di Prasasti Baru yang digambarkan melalui konsep matematika bangun datar lingkaran. Susanah (2017) mendefinisikan lingkaran sebagai himpunan titik-titik pada bidang datar yang berjarak sama ke sebuah titik (titik pusat). Pada pembelajaran matematika di sekolah, hiasan ini dapat dijadikan objek pada pembelajaran bangun datar untuk Kelas IV sesuai KD 3.9 yaitu menjelaskan dan menentukan keliling dan luas persegi, persegipanjang, dan segitiga serta hubungan pangkat dua dengan akar pangkat dua (Kemendikbud, 2018).

Selanjutnya, Prasasti Gulung-Gulung dan Prasasti Jeru-Jeru pada bagian atas/puncak yang terletak di sisi muka dan sisi belakang terdapat hiasan. Pada bagian sisi muka dan sisi belakang terdapat hiasan bunga teratai atau padma yang setengah mekar yang dihiasi dengan sulur-suluran yang digambarkan keluar dari jambangan. Dari hasil wawancara dapat diketahui bahwa motif hiasan bunga teratai atau padma yang digambarkan keluar dari jambangan merupakan salah satu ciri khas dari gaya seni Singasari serta dalam kesenian Hindu-Buddha, teratai atau padma merupakan tanaman penting yang dianggap sebagai penanda dari penciptaan, kesucian, kelahiran yang suci, dan sebagainya. Hiasan ini apabila ditarik sebuah garis vertikal tepat di titik tengah puncak prasasti tampak sama seperti pada gambar 15 dan gambar 16.

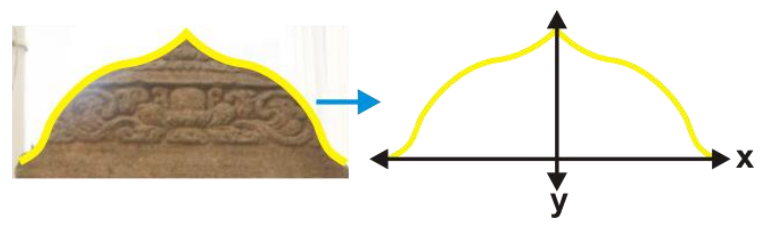

Gambar 14. Sketsa transformasi refleksi pada hiasan Prasasti Gulung-Gulung terhadap sumbu-y

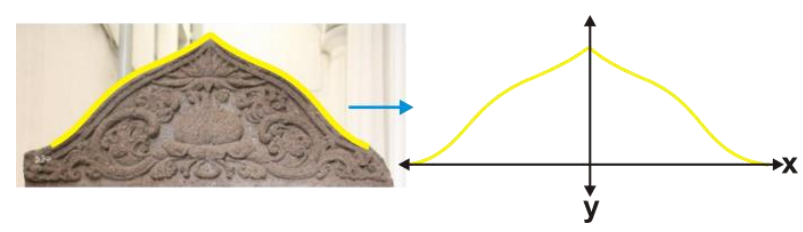

Gambar 15. Sketsa transformasi refleksi pada hiasan Prasasti Jeru-Jeru terhadap sumbu-y

Gambar 15 dan gambar 16 menunjukkan bahwa hiasan pada Prasasti Glung-Gulung dan Prasasti Jeru-Jeru mempunyai konsep transformasi geometri refleksi. Dari hal tersebut dapat diketahui bahwa masyarakat zaman dahulu menggunakan konsep transformasi geometri yaitu refleksi. Refleksi adalah cerminan dari suatu objek dengan jarak dan ukuran yang sama (Budiarto, 2006). Refleksi pada sumbu-y (vertikal), jika titik pada bayangan $\mathrm{P}(\mathrm{x}, \mathrm{y})$ adalah $\mathrm{P}^{\prime}\left(\mathrm{x}^{\prime}, \mathrm{y}^{\prime}\right)$ maka $\mathrm{P}^{\prime}\left(\mathrm{x}^{\prime}, \mathrm{y}^{\prime}\right)=\mathrm{P}^{\prime}(-\mathrm{x}, \mathrm{y})$. Bentuk matriks dapat ditulis sebagai berikut.

$$
\begin{aligned}
& \mathrm{x}^{\prime}=-\mathrm{x} \\
& \mathrm{y}^{\prime}=\mathrm{y}
\end{aligned}
$$




$$
\left(\begin{array}{l}
x^{\prime} \\
y^{\prime}
\end{array}\right)=\left(\begin{array}{cc}
-1 & 0 \\
0 & 1
\end{array}\right)\left(\begin{array}{l}
x \\
y
\end{array}\right) \quad \ldots
$$

Pada pembelajaran matematika di sekolah, hiasan pada permukaan batu Prasasti GulungGulung dan Prasasti Jeru-Jeru dapat dijadikan objek pada pembelajaran transformasi geometri untuk kelas IX sesuai KD 3.5 yaitu menjelaskan transformasi geometri (relfleksi, translasi, rotasi dan dilatasi) yang dihubungkan dengan masalah kontekstual (Kemendikbud, 2018).

\section{Isi Tulisan Prasasti}

Prasasti Kubu-Kubu, Prasasti Kaladi, Prasasti Harinjing, Prasasti Jeru-Jeru, Prasasti Linggasuntan, Prasasti Gulung-Gulung, Prasasti Baru, dan Prasasti Kamalagyan dikeluarkan sebagai anugerah raja karena beberapa alasan tertentu serta memuat penggunaan aksara angka, penggunaan lafal bilangan dan satuan ukuran. Delapan prasasti tersebut menggunakan aksara dan bahasa Jawa Kuna yang dipahatkan pada lempengan atau batu prasasti dibeberapa sisinya.

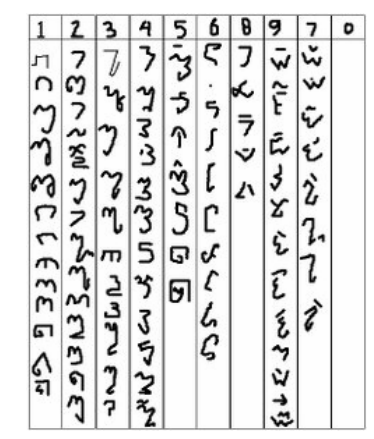

Gambar 16. Aksara angka Jawa Kuna

Sumber : Prabowo, 2010

Lafal bilangan yang digunakan terdapat lafal bilangan yang menyatakan tanggal, menyatakan banyaknya sesuatu, dan menyatakan kegiatan berulang. Berikut lafal bilangan yang digunakan pada prasasti-prasasti tersebut.

\section{Tabel 1.}

Lafal bilangan yang terdapat pada Prasasti Kubu-Kubu, Prasasti Kaladi, Prasasti Harinjing, Prasasti Jeru-Jeru, Prasasti Linggasuntan, Prasasti Gulung-Gulung, Prasasti Baru, dan Prasasti Kamalagyan

\begin{tabular}{|c|c|c|}
\hline $\begin{array}{c}\text { Lafal } \\
\text { Bilangan }\end{array}$ & Alihaksara dan Terjemahan & Keterangan \\
\hline \multirow{7}{*}{ Tanggal } & “...tithi pratipāda..." (tanggal 1) & Prasasti Kubu-Kubu, Harinjing, dan Kamalgyan \\
\hline & “...tithi saptami...” (tanggal 7) & Prasasti Baru \\
\hline & “...tithi aștami..." (tanggal 8) & Prasasti Kaladi \\
\hline & “...tithi nawami...” (tanggal 9) & Prasasti Gulung-Gulung \\
\hline & “...tithi ekāadaśī...” (tanggal 11) & Prasasti Harinjing dan Jeru-Jeru \\
\hline & "...tithi dwadaśī...” (tanggal 12) & Prasasti Linggasuntan \\
\hline & “...tithi pañcadaśī...” (tanggal 15) & Prasasti Harinjing \\
\hline \multirow{3}{*}{$\begin{array}{l}\text { Banyaknya } \\
\text { sesuatu }\end{array}$} & “...satngah..." (setengah) & Prasasti Gulung-Gulung \\
\hline & “...rway..." (dua) & Prasasti Kubu-Kubu dan Baru \\
\hline & “...kalih...””(dua) & $\begin{array}{l}\text { Prasasti Linggasuntan, Gulung-Gulung, dan Jeru- } \\
\text { Jeru }\end{array}$ \\
\hline
\end{tabular}




\begin{tabular}{|c|c|c|}
\hline & “...tlu..." (tiga) & Prasasti Linggasuntan dan Jeru-Jeru \\
\hline & “...tlung ..." (tiga) & Prasasti Kaladi dan Linggasuntan \\
\hline & “...trini..." (tiga) & Prasasti Kaladi dan Baru \\
\hline & “...tri..." (tiga) & \\
\hline & “...kapat...”"(empat) & Prasasti Kaladi \\
\hline & “...patang ...” (empat) & Prasasti Kubu-Kubu dan Linggasuntan \\
\hline & “...catur..." (empat) & Prasasti Kaladi dan Baru \\
\hline & “...kalima ...” (lima) & $\begin{array}{l}\text { Prasasti Kubu-Kubu, Linggasuntan, Gulung-Gulung, } \\
\text { dan Jeru-Jeru }\end{array}$ \\
\hline & “...pañca..." (lima) & $\begin{array}{l}\text { Prasasti Kaladi, Gulung-Gulung, Jeru-Jeru, dan } \\
\text { Baru }\end{array}$ \\
\hline & “...pitu ...” (tujuh) & Prasasti Harinjing \\
\hline & “...aștā $\ldots ”($ delapan $)$ & Prasasti Kaladi \\
\hline & “...kasanga ..." (sembilan) & Prasasti Jeru-Jeru \\
\hline & “...sapuluh...”" (sepuluh) & Prasasti Kaladi \\
\hline & “...sahasra ..." (seribu) & Prasasti Gulung-Gulung dan Jeru-Jeru \\
\hline & “...pisan ..." (satu kali) & Prasasti Kamalagyan \\
\hline Keherulangan & “...ping̣wa ...” (dua kali) & Prasasti Gulung-Gulung dan Kamalagyan \\
\hline Kederurangan & “...pitiga ...” (tiga kali) & $\begin{array}{l}\text { Prasasti Linggasuntan, Gulung-Gulung, dan Jeru- } \\
\text { Jeru }\end{array}$ \\
\hline
\end{tabular}

Lambang bilangan dan lafal bilangan yang terdapat dalam prasasti tersebut tidak dianjurkan diterapkan dalam pembelajaran matematika karena menggunakan aksara dan bahasa Jawa Kuna yang saat ini sudah tidak digunakan dalam kehidupan sehari-hari. Namun, bilangan dan lafal bilangan tersebut dapat digunakan untuk mengenalkan bilangan yang dimiliki masyarakat Jawa Kuna sebagai sejarah budaya lokal. Beberapa lafal bilangan seperti tri/trini, catur, pañca, aștā, dan sahasra merupakan adopsi dari angka sansekerta dan hingga saat ini lafal bilangan tersebut masih digunakan dalam beberapa penulisan, contohnya pancasila, caturwarna, trisemester, dsb.

Selain penggunaan lafal bilangan terdapat juga pengunaan satuan ukuran yang termuat dalam Prasasti Kubu-Kubu, Prasasti Kaladi, Prasasti Harinjing, Prasasti Linggasuntan, Prasasti GulungGulung, Prasasti Jeru-Jeru, Prasasti Baru, dan Prasasti Kamalagyan. Beberapa diantaranya terdapat satuan ukuran uang emas dan perak, satuan ukuran luas, satuan ukuran panjang, satuan ukuran kain, satuan ukuran hewan ternak, satuan ukuran barang dagang, dan satuan ukuran lainnya.

Tabel 2.

Satuan ukuran pada Prasasti Kubu-Kubu, Prasasti Kaladi, Prasasti Harinjing, Prasasti Jeru-Jeru, Prasasti Linggasuntan, Prasasti Gulung-Gulung, Prasasti Baru, dan Prasasti Kamalagyan

\begin{tabular}{|c|c|c|c|}
\hline $\begin{array}{c}\text { Nama } \\
\text { Prasasti }\end{array}$ & \begin{tabular}{|c|}
$\begin{array}{c}\text { Ukuran } \\
\text { dan } \\
\text { Satuan }\end{array}$ \\
\end{tabular} & Kutipan Alihaksara dan Terjemahan & Keterangan \\
\hline \multirow[t]{3}{*}{ Kubu-Kubu } & Kain & $\begin{array}{l}\text { “...wdihan } 1 . . . ”(1 \text { kain untuk laki-laki) } \\
\text { “...wdihan pan̆alih sadugala ...”(1 yugala kain jenis Paňalih) }\end{array}$ & \multirow{3}{*}{$\begin{array}{l}\text { (Khakam \& } \\
\text { Susanti, } \\
2014 ; \\
\text { Zoetmulder } \\
\& \text { Robson, } \\
\text { 1995) }\end{array}$} \\
\hline & Panjang & $\begin{array}{l}\text { “...talay rway tapak...” (artinya pipa saluran air sebesar dua } \\
\text { tapak) } \\
\text { “...ri kubu kubu patay tapak...” (ke Kubu-Kubu sebesar empat } \\
\text { tapak) }\end{array}$ & \\
\hline & Uang & $\begin{array}{l}\text { “... wineh } \boldsymbol{k u} 2 . . . ”(\text { diberi uang } 2 \text { kupang }) \\
\text { "...wineh ma 1..."(diberi uang } 1 \text { masa })\end{array}$ & \\
\hline
\end{tabular}




\begin{tabular}{|c|c|c|c|}
\hline \multirow[t]{3}{*}{ Kaladi } & Kain & 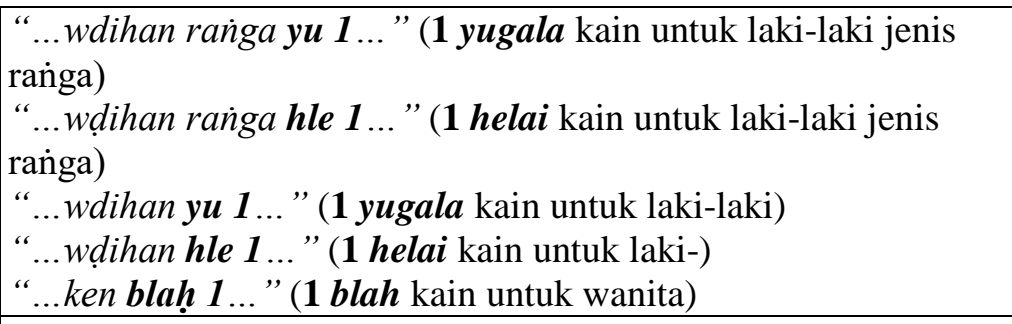 & \multirow[t]{3}{*}{$\begin{array}{l}\text { (Nayenggita, } \\
2012 ; \\
\text { Zoetmulder } \\
\text { \& Robson, } \\
1995)\end{array}$} \\
\hline & Panjang & “...telun dpa kapat siho...” (tiga $d p a$ dan empat siho $)$ & \\
\hline & Uang & “...ma su 1 m̄̄ 4 ...” (emas 1 suwarna dan 4 māsa $)$ & \\
\hline \multirow[t]{2}{*}{ Harinjing } & Luas & “...lmah satamwah ...” (tanah seluas satu tamwah) & \multirow{2}{*}{$\begin{array}{l}\text { (Kurnia, } \\
2018 ; \\
\text { Zoetmulder } \\
\text { \& Robson, } \\
1995)\end{array}$} \\
\hline & Uang & 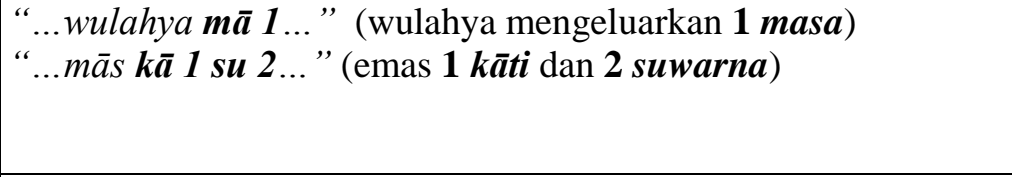 & \\
\hline \multirow[t]{4}{*}{ Jeru-Jeru } & $\begin{array}{l}\text { Barang } \\
\text { Dagang }\end{array}$ & $\begin{array}{l}\text { “...adagang kapas. wuikkudu kasanga bantal. abasana kalima } \\
\text { bantal...”(pedagang kapas, mengkudu sembilan buntalan, } \\
\text { pedagang pakaian lima buntalan) }\end{array}$ & \multirow{11}{*}{$\begin{array}{l}\text { (Brandes, } \\
1913 ; \\
\text { Trigangga \& } \\
\text { Hardiati, } \\
\text { 2003; } \\
\text { Zoetmulder } \\
\text { \& Robson, } \\
1995)\end{array}$} \\
\hline & $\begin{array}{l}\text { Hewan } \\
\text { Ternak }\end{array}$ & $\begin{array}{l}\text { “...kbo sawurugan. sapi prana 3. wdus saragang anulang } \\
\text { andah satarub...” (kerbau satu kandang, sapi } \mathbf{3} \text { ekor, kambing } \\
\text { satu ragang, memelihara itik satu kandang) }\end{array}$ & \\
\hline & Kain & 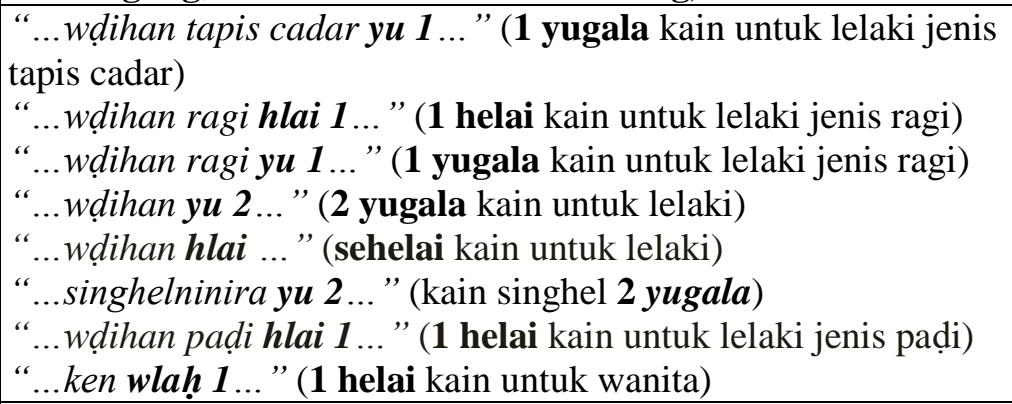 & \\
\hline & Uang & $\begin{array}{l}\text { “...mas su } 5 \ldots ”(5 \text { suwarna } \text { uang emas }) \\
\text { “...ma } 2 \text { ku } 2 \ldots ”(2 \text { masa } \text { dan } 2 \text { kupang })\end{array}$ & \\
\hline \multirow[t]{4}{*}{ Linggasuntan } & $\begin{array}{l}\text { Barang } \\
\text { Dagang }\end{array}$ & $\begin{array}{l}\text { “...dwal pinikul kalima bantal...”" (dijual dengan dipikul } \\
\text { batasnya lima buntalan) }\end{array}$ & \\
\hline & $\begin{array}{l}\text { Hewan } \\
\text { Ternak }\end{array}$ & “...anḍah sawantayan ..." (itik satu kelompok) & \\
\hline & Kain & 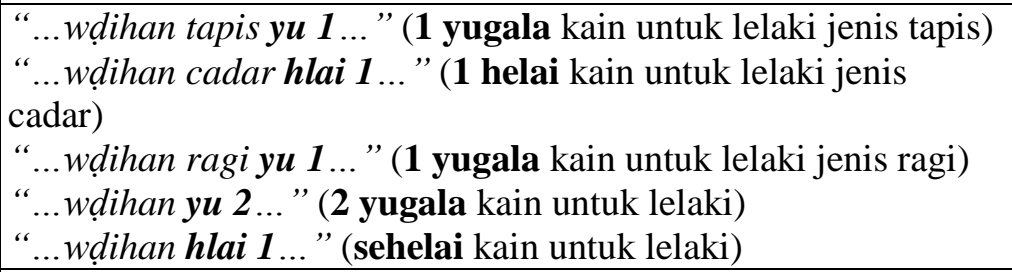 & \\
\hline & Uang & $\begin{array}{l}\text { “...mas su } 1 \text { ma 4...” (1 suwarna dan } 4 \text { masa uang emas }) \\
\text { “...ma } 1 \text { ku } 2 \ldots .(1 \text { masa dan } 2 \text { kupang })\end{array}$ & \\
\hline \multirow[t]{3}{*}{$\begin{array}{l}\text { Gulung- } \\
\text { Gulung }\end{array}$} & \begin{tabular}{|l} 
Barang \\
Dagang
\end{tabular} & "...kalima bantal..." (lima buntalan) & \\
\hline & $\begin{array}{l}\text { Hewan } \\
\text { Ternak }\end{array}$ & $\begin{array}{l}\text { “...kbo sawurugan. sapi prana 3. wdus saragang anulang } \\
\text { andah satarub...” (kerbau satu kandang, sapi } 3 \text { ekor, kambing } \\
\text { satu ragang, memelihara itik satu kandang) }\end{array}$ & \\
\hline & Kain & 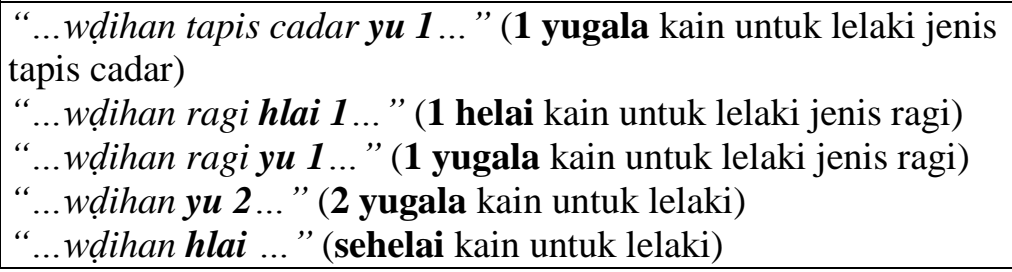 & \\
\hline
\end{tabular}




\begin{tabular}{|c|c|c|c|}
\hline & & 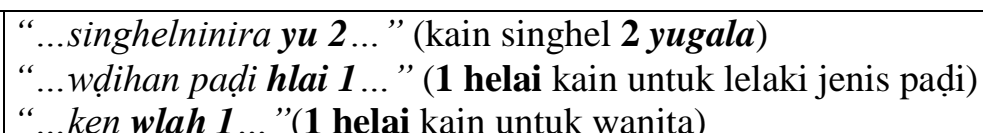 & \\
\hline & $\begin{array}{l}\text { Kapasitas } \\
\text { Barang } \\
\end{array}$ & $\begin{array}{l}\text { “...i air gilang lía watu sukat 20...” (di Air Gilang minyak } 20 \\
\text { sukat) }\end{array}$ & \\
\hline & Panjang & $\begin{array}{l}\text { “...gulunggulung tapak su } 7 . . . ”(\text { Gulunggulung sebesar } 7 \\
\text { tapak) }\end{array}$ & \\
\hline & Uang & $\begin{array}{l}\text { “...mas su } 5 \text {...” (5 suwarna uang emas }) \\
\text { “...ma } 2 \text { ku } 2 \ldots ”(2 \text { masa } \text { dan } 2 \text { kupang })\end{array}$ & \\
\hline \multirow[t]{2}{*}{ Baru } & Kain & $\begin{array}{l}\text { “...wdihan yuga 1...” (kain bebed } 1 \text { yugala }) \\
\text { “...wdihan hlai } 1 \text {...” (kain bebed } 1 \text { helai) } \\
\text { “...ragi hlai...” (kain bebed jenis ragi } 1 \text { helai) }\end{array}$ & \multirow{4}{*}{$\begin{array}{l}\text { (Yulianto, } \\
1996 ; \\
\text { Zoetmulder } \\
\text { \& Robson, } \\
1995 \text { ) }\end{array}$} \\
\hline & Uang & $\begin{array}{l}\text { “...ka } 2 \text { ma su 10..." (2 kati dan } 10 \text { suwarna emas }) \\
\text { “...ma } 1 \text { ku } 1 \text {..." (1 masa dan } 1 \text { kupang })\end{array}$ & \\
\hline \multirow[b]{2}{*}{ Kamalagyan } & Luas & “...masawah tampah 6...”" (sawah seluas 6 tampah) & \\
\hline & Uang & $\begin{array}{l}\text { “...ma su } 17 \text { mā } 14 \text { ku } 14 \text { sā } 4 \ldots ” \\
\text { (17 suwarnna masa emas, } 14 \text { kupang dan } 14 \text { masa } 4 \text { satak) }\end{array}$ & \\
\hline
\end{tabular}

Satuan kain yang digunakan ada satuan hlai atau yang dapat diartikan dengan kata helai (1 potong kain) untuk menghitung banyaknya kain wdihan biasa, jenis cadar, jenis ragi, jenis ranga, dan jenis padi. Satuan yugala atau yang dapat diartikan dengan kata sepasang (2 potong kain) untuk menghitung banyaknya kain wdihan biasa, jenis panalih, jenis ragi, jenis ranga, jenis tapis, jenis tapis cadar, dan kain singhel. Sedangkan, satuan wlah (blah) yang diartikan dengan kata 1 potong kain untuk menghitung banyaknya kain ken.

Satuan panjang yang digunakan ada satuan tapak, dpa dan siho. Satuan dpa sampai saat ini masih digunakan masyarakat jawa dalam mengukur panjang tanah. Ukuran satu dpa merupakan panjang dari rentang kedua tangan dan 1 dpa setara dengan 1,6m $-2 \mathrm{~m}$. Sedangkan,satuan luas yang digunakan ada satuan tamwah/tampah. Setiap 1 tampah setara dengan $6.750-7.680 \mathrm{~m}^{2}$.

Satuan uang emas yang digunakan ada satuan kati, suwarnna, kupang, masa, dan satak. Satuan ukuran uang emas menurut Wicks (dalam Darmosoetopo, 2003; Setrawati, 2009) menyatakan berat emas pada jawa kuna setiap 1 kati = 16 swarna, 1 swarna $=16$ masa, 1 masa $=4$ kupang, 1 atak $($ satak $)=2$ kupang dengan berat masing-masing satuannya adalah 1 swarna $=38,601$ gr, 1 masa $=$ 2,414 gr, 1 kupang = 0,603 gr.

Satuan-satuan ukur lain yang termuat ada bantal yang digunakan sebagai satuan ukuran barang dagang yang berkaitan dengan pakaian. Setiap satu bantal setara dengan $15 \mathrm{~kg}$. Kemudian, ada satuan sukat yang digunakan untuk menyatakan satuan ukuran minyak. Zeotmulder (1995) menyatakan bahwa satuan sukat tidak hanya digunakan untuk menyatakan ukuran minyak namun juga untuk menyatakan ukuran kapasitas barang seperti beras, bawang, dan lainnya. Selanjunnya, satuan wurugan, rangang, dan tarub digunakan sebagai satuan ukur hewan ternak. Satuan tarub selain digunakan sebagai satuan ukur hewan ternak juga digunakan sebagai satuan ukur pekerja yang berada dalam satu ruang/tempat karena kata tarub sendiri mempunyai arti bangsal atau ruang kerja. 
Satuan dibagi menjadi dua yakni satuan baku dan tidak baku. Satuan tidak baku adalah satuan yang tidak ditetapkan sebagai satuan pengukuran secara umum atau secara ilmiah karena tidak dinyatakan dengan jelas atau tidak dapat digunakan untuk memeriksa ketepatan suatu instrumen, sedangkan satuan baku adalah satuan yang ditetapkan sebagai satuan pengukuran secara umum karena dinyatakan dengan jelas dan dapat dipakai untuk memeriksa suatu ketepatan instrument (Handayani, Sumarno, \& Haryati, 2017). Satuan ukuran berat uang emas yang digunakan pada prasasti ini dapat dinyatakan sebagai satuan tidak baku karena tidak ditetapkan sebagai satuan ukuran umum.

Satuan-satuan ukuran ini dapat digunakan sebagai pengenalan satuan tidak baku pada materi pengukuran untuk kelas III dan kelas IV. Selain itu, satuan ukuran yang terdapat ditulisan prasasti pada bagian pembagian hadiah (pasek-pasek) sebagai balasan atas jasa pada penetapan sima digunakan dalam prasasti ini juga dapat digunakan dalam materi aljabar untuk Kelas VII sesuai dengan KD 3.5 yaitu menjelaskan sistem persamaan linear dua variabel dan penyelesaiannya yang dihubungkan dengan masalah kontekstual (Kemendikbud, 2018). Pemberian hadiah yang berupa kain dengan jenis dan jumlah yang berbeda-beda serta hadiah berupa uang dengan satuan berat yang berbagai macam ini dapat digunakan sebagai masalah kontekstual dalam pembuatan soal yang terkait dengan sistem persamaan linear dua variabel dan penyelesaiannya.

Selanjutnya, pemberian hadiah dengan jumlah yang berbeda kepada masing-masing pejabat yang berjasa dalam pembuatan prasasti yang ada pada isi tulisan prasasti juga dapat dibuat menjadi himpunan-himpunan. Masriyah (2016) mengatakan himpunan adalah kumpulan objek dalam wujud abstrak atau kongkret yang mempunyai syarat tertentu dan jelas. Himpunan dapat digambarkan dalam bentuk diagram yang disebut diagram Venn (2016). Berikut salah satu bentuk diagram Venn dari himpunan penerima hadiah pada Prasasti Jeru-Jeru.

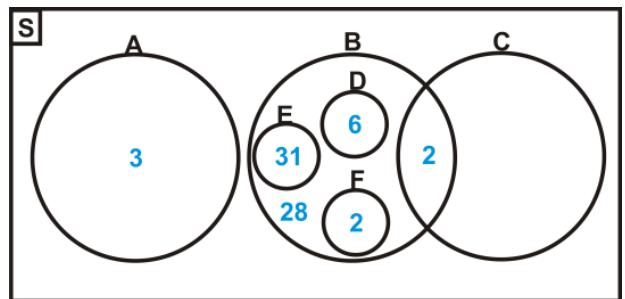

Gambar 17. Diagram venn penerima hadiah dari Rakryan Hujung
Keterangan :

$\mathbf{S}=$ Himpunan penerima hadiah dari Rakryan Hujung berdasarkan prasasti jeru-jeru

$\mathbf{A}=$ Himpunan penerima hadiah berupa kain ken dari Rakryan Hujung berdasarkan prasasti jeru-jeru

$\mathbf{B}=$ Himpunan penerima hadiah berupa kain wdihan dari Rakryan Hujung berdasarkan prasasti jeru-jeru

$\mathbf{C}=$ Himpunan penerima hadiah berupa kain singhel dari Rakryan Hujung berdasarkan prasasti jeru-jeru

$\mathbf{D}=$ Himpunan penerima hadiah berupa kain wdihan jenis tapis cadar dari Rakryan Hujung berdasarkan prasasti jeru-jeru

$\mathbf{E}=$ Himpunan penerima hadiah berupa kain jenis wdihan ragi dari Rakryan Hujung berdasarkan prasasti jeru-jeru

$\mathbf{F}=$ Himpunan penerima hadiah berupa kain wdihan jenis padi dari Rakryan Hujung berdasarkan prasasti jeru-jeru

berdasarkan Prasasti Jeru-Jeru

Gambar 18 menunjukkan bahwa pada diagram venn tersebut memuat hubungan antar himpunan seperti subset, irisan himpunan, gabungan himpunan, dan himpunan yang saling pisah. Konsep himpunan ini dapat digunakan untuk materi himpunan Kelas VII sesuai KD 3.5 yaitu menjelaskan himpunan, himpunan bagian, himpunan semesta, himpunan kosong, komplemen darhimpunan, dan melakukan operasi biner pada himpunan menggunakan masalah kontekstual (Kemendikbud, 2018). 
Selain dapat digunakan dalam materi himpunan, daftar jumlah penerima hadiah juga dapat digunakan dalam materi statistika. Salah satunya pada Prasasti Linggasuntan. Hadiah-hadiah berupa kain yang diberikan berdasarkan isi tulisan Prasasti Linggasuntan dapat dilihat pada tabel 3.

\section{Tabel 3.}

Jumlah Penerima Hadiah Berupa Kain dari Rama Linggasuntan dalam Prasasti Linggasuntan

\begin{tabular}{|c|l|c|}
\hline No & Jenis kain yang diterima & Jumlah penerima (orang) \\
\hline 1 & Wdihan & 37 \\
\hline 2 & Wdihan jenis tapis & 1 \\
\hline 3 & Wdihan jenis cadar & 14 \\
\hline 4 & Wdihan jenis ragi & 7 \\
\hline \multicolumn{2}{|c|}{ Total } & 59 \\
\hline
\end{tabular}

Berdasarkan tabel 3 dapat dibentuk diagram batang dan diagram lingkaran seperti pada gambar 19 dan gambar 20. Diagram batang adalah jenis diagram yang berbentuk persegipanjang dengan lebar sama dan dilengkapi skala atau ukuran yang sesuai dengan data yang diperoleh, sedangkan diagram lingkaran adalah jenis diagram yang berupa lingkaran yang telah dibagi menjadi beberapa juring sesuai dengan data yang diperoleh (Iqbal \& Hasan, 2002). Penyajian data dengan berbagai bentuk ini dapat digunakan sebagai bahan ajar matematika materi statistika kelas VII sesuai dengan KD 3.9 yaitu menganalisis hubungan antara data dengan cara penyajiannya (tabel, diagram garis, diagram batang, dan diagram lingkaran) (Kemendikbud, 2018).

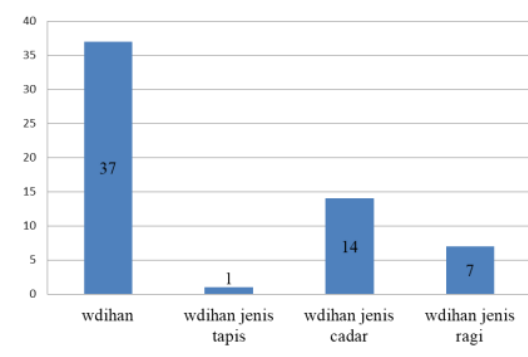

Gambar 18. Diagram batang jumlah penerima hadiah berupa kain dalam Prasasti Linggasuntan

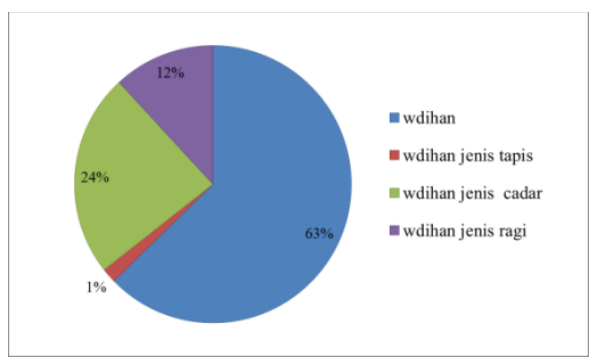

Gambar 19. Diagram lingkaran jumlah penerima hadiah berupa kain dalam Prasasti Linggasuntan

Gambar 19 menunjukkan penyajian data pada tabel 3 berupa diagram batang. Diagram batang digunakan dalam menyajikan data yang berkategori. Sedangkan, gambar 20 menunjukkan penyajian data pada tabel 3 berupa diagram lingkaran dalam persentase. Sama halnya dengan diagram batang, diagram lingkaran juga digunakan dalam menyajikan data yang berkategori.

\section{KESIMPULAN}

Dari pembahasan yang telah disampaikan, maka diperoleh kesimpulan sebagai berikut. Pertama, berdasarkan bentuk fisiknya, prasasti yang terbuat dari tembaga yaitu Prasasti Kubu-Kubu dan Kaladi serta prasasti dengan puncak akolade yaitu Prasasti Gulung-Gulung dan Jeru-Jeru 
menerapkan konsep matematika persegipanjang. Prasasti dengan puncak setengah lingkaran yaitu Prasasti Harinjing dan Linggasuntan bentuk fisiknya menerapkan konsep matematika lingkaran dan trapesium. Prasasti dengan puncak runcing yaitu Prasasti Baru dan Kamalagyan menerapkan konsep segitiga, trapesium, segilima. Kedua, berdasarkan hiasan yang terpahat pada Prasasti Harinjing, Gulung-Gulung, Jeru-Jeru, dan Baru menerapkan konsep matematika geometri transformasi yaitu translasi dan refleksi serta lingkaran. Ketiga, berdasarkan isinya kedelapan prasasti tersebut memuat penggunaan bilangan baik menggunakan aksara angka jawa kuna ataupun dengan melafalkannya menggunakan bahasa jawa kuna untuk menunjukkan tanggal, banyaknya sesuatu dan keberulangan. Memuat beberapa satuan dan ukuran jawa kuna, diantaranya : satuan panjang (dpa, siho, tapak), satuan uang emas dan perak (satak, kupang, masa, kati, suwarna), satuan luas (tampah), satuan kain (hlai/hle, wlah/blah, yugala/dugala), dan satuan-satuan lain (wurugan, raingang, tarub, bantal, sukat).

Tulisan prasasti bagian pembagian hadiah dapat diterapkan pada matematika materi himpunan dan penyajian data. Secara keselurahan konsep yang termuat pada kedelapan prasasti ini dapat digunakan pada pembelajaran matematika untuk jenjang SD kelas III, IV, dan VI, serta SMP kelas VII, VIII, dan IX. Untuk selanjutnya dapat dilakukan eksplorasi tentang konsep matematika pada benda-benda budaya yang mempunyai nilai sejarah dan moral sehingga siswa selain belajar matematika juga dapat mengenal budaya dan sejarah yang dimiliki. Selain itu, perlu dikembangkan lembar kerja siswa berbasis budaya pada prasasti.

\section{DAFTAR PUSTAKA}

Ardiyanto, F. (2015, February 27). Prasasti Media Komunikasi Masa Lampau - Balai Pelestarian Cagar Budaya Yogyakarta. Retrieved Januari 7, 2020, from https://kebudayaan.kemdikbud.go.id/bpcbyogyakarta/prasasti-media-komunikasi-masa-lampau/

Bishop, A. (1994). Cultural Conflicts in Mathematics Education: Developing a Research Agenda. For the Learning of Mathematics.

Bishop, A. J. (1997). The relationship between mathematics education and culture. Iranian Mathematics Education Conference.

Brandes, J. L. A. (1913). Verhandelingen van het Bataviaasch Genootschap: Oud Javaansche oorkonden Nagelaten transscripties. Batavia: Albrecht \& co.

Budiarto, M. T. (2006). Geometri Transformasi. Surabaya: UNESA University Press.

Budiarto, M. T. (2015). Geometri Transformasi (8th ed.). Surabaya: UNESA University Press.

Budiarto, M. T. (2016a). Etno-Matematika : Sebagai Batu Pijakan Untuk Pembelajaran Matematika. Prosiding Seminar Nasional Pendidikan Matematika.

Budiarto, M. T. (2016b). Peran matematika dan pembelajarannya dalam mengembangkan kearifan budaya lokal untuk mendukung pendidikan karakter bangsa. Seminar Nasional Pendidikan Matematika, 1-11. Yogyakarta: Gading Pustaka.

D'Ambrosio, U. (1985). Ethnomathematics and its Place in the History and Pedagogy of Mathematics. For the Learning of Mathematics - An International Journal of Mathematics Education.

D’Ambrosio, U. (1999). Literacy, Matheracy, and Technocracy: A Trivium for Today. Mathematical Thinking and Learning. https://doi.org/10.1207/s15327833mt10102_3 
Darmosoetopo, R. (2003). Sima dan bangunan keagamaan di Jawa abad ix-x TU. Prana Pena.

Handayani, S., Sumarno, \& Haryati, Y. (2017). Upaya Meningkatkan Kemampuan Kognitif Dalam Memperkenalkan Konsep Pengukuran Anak Usia Dini Melalui Metode Bermain Peran. JKPM, $4(1), 19-42$.

Hardiarti, S. (2017). ETNOMATEMATIKA: APLIKASI BANGUN DATAR SEGIEMPAT PADA CANDI MUARO JAMBI. AKSIOMA. https://doi.org/10.26877/aks.v8i2.1707

Iqbal, M., \& Hasan, H. (2002). Pokok-pokok Materi Statistik I ( Statistik Deskriptif). In Statistik deskriptif. https://doi.org/10.1007/b137665

Karim, M. A., \& Hidayanto, E. (2014). Modul 1 Bangun Datar. Pendidikan Matematika II, 1-43.

Kemendikbud. (2018). Permendikbud 37 tahun 2018. Jakarta.

Khakam, G. A., \& Susanti, N. (2014). Prasasti Kubu Kubu 827 Śaka: Tinjauan Ulang (Naskah Ringkas). Retrieved from http://lib.ui.ac.id/naskahringkas/2016-10/S55122-Galih Abi Khakam

Kurnia, I. (2018). Mengungkap Nilai-Nilai Kearifan Lokal Kediri Sebagai Upaya Pelestarian Budaya Bangsa Indonesia. Jurnal PGSD. https://doi.org/10.33369/pgsd.11.1.51-63

Masriyah. (2016). Dasar-Dasar Matematika. Surabaya: UNESA University Press.

Nayenggita, A. (2012). Prasasti Kaladi 831 Saka. Universitas Indonesia.

Nuh, Z. M., \& Dardiri. (2017). Etnomatematika Dalam Sistem Pembilangan Pada Masyarakat Melayu Riau. Kutubkhanah.

Prabowo, A., Tripena, A., \& Sugandha, A. (2017). PRASASTI TUGU DALAM PERSPEKTIF MATEMATIKA DAN ASTRONOMI. Prosiding, 7(1).

Risdiyanti, I., \& Prahmana, R. C. I. (2018). Ethnomathematics: Exploration in javanese culture. Journal of Physics: Conference Series, 943(1), 12032.

Rosa, M., \& Clark, D. (2011). Ethnomathematics: the cultural aspects of mathematics. Revista Latinoamericana de Etnomatemática.

Setrawati, N. (2009). Perdagangan pada Masa Pu Sindok Berdasarkan Data Prasasti. Universitas Indonesia.

Spradley, J. P. (2006). Metode Etnografi, Terjemahan, edisi II cetakan ke-1. Yogyakarta: Tiara Wacana, xiv.

Suharjana, A., Markaban, \& Sasongko, H. W. (2013). Geometri Datar dan Ruang di SD. In PPPPTK Matematika. https://doi.org/10.1017/CBO9781107415324.004

Susanah, S. (2017). Geometri Analitik (Revisi). Surabaya: UNESA University Press.

Trigangga, \& Hardiati, E. S. (2003). Tiga Prasasti Batu Jaman Raja Sindok. Jakarta: Museum Nasional Indonesia.

Wahyuni, A., Aji, A., Tias, W., \& Sani, B. (2013). Peran Etnomatematika dalam Membangun Karakter Bangsa: Penguatan Peran Matematika Dan Pendidikan Matematika Untuk Indonesia Yang Lebih Baik.

Yulianto, N. S. (1996). Prasasti-Prasasti Sekitar Masa Pemerintahan Raja Airlangga: Suatu Kajian Analitis. Depok.

Zaenuri, \& Dwidayati, N. (2018). Menggali Etnomatematika: Matematika sebagai Produk Budaya. Prisma. Prosiding Seminar Nasional Matematika.

Zamzam, F., \& Firdaus. (2018). Aplikasi Metodologi Penelitian. Yogyakarta: Deepublish.

Zoetmulder, P. J., \& Robson, S. O. (1995). Kamus Jawa Kuna-Indonesia: PY (Vol. 2). PT Gramedia Pustaka Utama. 